Krystyna Wróbel-Lipowa

Instytut Historii

Wydziat Humanistyczny

Uniwersytet Marii Curie-Sktodowskiej w Lublinie

\title{
Model wychowania $w$ rodzinie ziemiańskiej w pierwszej połowie XIX wieku na przykładzie domu Stanisława Kostki Zamoyskiego i jego córki Celiny Działyńskiej
}

\begin{abstract}
Upbringing of children in aristocratic families in the first half of the 19th century, based on Stanislaw Kostka Zamoyski and his daughter Celina Działyński

Upbringing and education was a matter of great importance among the Polish landed gentry. The education of male descendants was particularly essential, because they were expected to hold important office, increase the family's wealth and possessions and become a source of pride to the family in the future. According to Stanislaw Kostka Zamoyski XII, Majoratsherr in Zamość, the family home set the best example of upbringing to the younger family members. Therefore, children needed to have positive role models in their parents, who would provide them with advice, care and look after them. Small children were introduced to harsh conditions of everyday life. In order to positively shape children's personalities, to help them to become open, gentle, reasonable, and kind people, teachers were not allowed to set them a bad example. The XII Majoratsherr's children in Zamość were raised by parents who called for strict obedience and respect. Stanisław Kostka Zamoyski's daughter Celina Działyńska raised her offspring in the same manner. She taught them respect for ordinary people - service and help for the needy. The above mentioned methods produced a positive effect in the future. Children raised in this way became aware of their responsibilities to the family and homeland.
\end{abstract}

Keywords: education, upbringing, aristocracy education, 19th century.

W polskich rodzinach ziemiańskich od dawna sprawa wychowania potomstwa była ważnym zadaniem. Tak też było w domu Stanisława Kostki Zamoyskiego, XII ordynata na Zamościu. Ideałem rodu Zamoyskich był typ szlachcica silnego i zdrowego, który powinien zajmować się sprawami publicznymi i wojskowymi. Według panującej tradycji dotyczącej wychowania w rodzinach magnackich, Stanisław K. Zamoyski postanowił sam kierować od wczesnych lat wychowaniem i kształceniem swoich dzieci.

Stanisław K. Zamoyski był synem kanclerza wielkiego koronnego Andrzeja. Wcześnie utracił ojca, a wówczas jego edukacją zajęła się matka, Konstancja z Czartoryskich, od- 
dając go całkowicie pod opiekę nauczyciela domowego młodych Zamoyskich, Stanisława Staszica, znienawidzonego zresztą w krótkim czasie przez swoich wychowanków (Stanisława Kostkę i jego starszego brata Aleksandra).

Wzorem do naśladowania dla XII ordynata na Zamościu były czyny i zachowania wielkiego jego przodka, kanclerza koronnego Jana Zamoyskiego. Wspominał także swoje wychowanie w dzieciństwie i wczesnej młodości, kiedy jego przedsięwzięcia tłumione były wychowaniem domowym w dodatku kobiecym, matczynym, co jak twierdził w konsekwencji wytworzyło brak wiary w swoją wartość ${ }^{1}$. Uważał, że powinien zaoszczędzić tego swoim dzieciom, dla których przykład najlepszy do naśladowania to dom rodzinny. Obowiązkiem zaś rodziców jest służyć dzieciom radą, opieką i wspomagać w dobrym zachowaniu.

Stanisław K. Zamoyski i jego małżonka Zofia z Czartoryskich mieli dziesięcioro dzieci: siedmiu synów i trzy córki. Sporządzona osobiście przez S.K. Zamoyskiego instrukcja tycząca wychowania i kształcenia starszych synów ordynata (Konstantego, Andrzeja-Artura, Jana i Władysława), daje obraz jak widział on wychowanie swoich dzieci. W instrukcji ojciec kreślił dla nich szczegółowo rozkład dnia. Dzieci wstawać musiały o godzinie w pół do szóstej rano. O godzinie szóstej powinny być już ubrane. Następnie twarz i uszy umyć zimną wodą, przyniesioną przez służącego do pokoju poprzedniego dnia². Umyć zęby, używając każdy swojej szczoteczki, włosy uczesać i szczoteczką wyczyścić głowę. Ręce umyć mydłem, a potem natrzeć ciastem migdałowym. Uklęknąć, głośno zmówić pacierz, tj. Ojcze Nasz, Zdrowaś Maryjo i Wierzę w Boga. Potem powiedzieć sobie dzień dobry, jak przyjaciele i pozdrowić nauczyciela przełożonego. Służący kładł wieczorem koło łóżek bieliznę i suknie przygotowane do ubrania nazajutrz, aby chłopcy sami mogli się rano ubierać. Nosić mieli codziennie białe koszule. W zimie zmiana koszul następowała co dwa dni. W pozostałych porach roku codziennie. W czasie błotnej jesieni chłopcy powinni chodzić w butach, w czasie zimna w kamaszach, a w inne dni w trzewikach. Każdy z chłopców powinien mieć jedną parę butów, trzy pary trzewików na spacer i jedną parę do tańca. Zmiana pończoch miała być co dwa dni lub częściej, zależnie od potrzeby. W czasie deszczowych, mokrych dni w przypadku mocno zamoczonych nóg, chłopcy po powrocie do domu powinni zmienić obuwie i pończochy. Obuwie i rękawiczki kupowano dzieciom z ich pensji otrzymywanej od rodziców. O ubiorze chłopców mówiło się wyraźnie, że na obiad i w święta lub kiedy wychodzą, mają być ubierani w nowe suknie, natomiast w domu podczas nauki pozostawać w starych. Rozkład zajęć w ciągu dnia, sporządzony przez Stanisława K. Zamoyskiego, ukazuje brak miejsca na bezczynność i lenistwo chłopców. Jego zdaniem synowie powinni maksymalnie wykorzystać czas przeznaczony na naukę, a tylko w godzinach przeznaczonych na rekreację z niej korzystać. Nauczyciel miał obowiązek baczenia, aby dzieci były ze sobą w przyjaźni, nie dokuczały sobie wzajemnie. Powinien zwracać uwagę, kiedy młodsi przychodzą do starszych braci, aby z należytą uprzejmością się z nimi witali, a wszyscy nauczycielowi-wychowawcy okazywali należny szacunek. Za najmniejsze nieposłuszeń-

1 Archiwum Główne Akt Dawnych, Archiwum Zamoyskich (dalej AGAD,AZ), sygn. 123, k. 5-6.

2 Ibidem, sygn. 108, k. 13. 
stwa lub innego rodzaju złe zachowanie przewidziane były kary, jak: klęczenie kwadrans lub dłużej, nieotrzymywanie kolacji, zabieranie 8 dukatów z pensji otrzymywanej od rodziców, a jeśli i to by nie pomogło, należy zawiadomić ojca w celu surowszego ukarania. S. Kostka Zamoyski uważał, że dzieci należy wcześnie przyzwyczajać do twardego codziennego życia i nie przyzwyczajać do pieszczot domowych, dlatego też chłopcy zwykle mieszkali osobno od rodziców ze swoimi guwernerami. Tak było, kiedy ordynat w 1806 r. wyjechał z całą rodziną z kraju do Wiednia, chłopcy (Konstanty ur. w 1799 r., Andrzej-Artur ur. w 1800 r., Jan ur. w 1802 r., Władysław ur. w 1803 r.) zamieszkali nie z rodzicami, lecz w osobnym domu, zwanym „Kiksches Haus”, na trzecim piętrze. Opiekę nad nimi sprawowali dwaj guwernerzy: Francuz, ksiądz d’Esquiroux (dla Konstantego i Andrzeja) i Polak Baliński (dla Jana i Władysława). Rodziców synowie odwiedzali tylko w niedziele. Chłopców dosyć wcześnie przygotowywano do podstawowych umiejętności wojskowych. Jednym z nich była nauka musztry z karabinem. Lekcji tych udzielał podoficer piechoty, rodem z Belgii, mówiący po polsku. Podobnie było po powrocie do kraju W początkach 1814 r. Stanisław Kostka zawiózł swoich synów do Warszawy, ale oczywiście nie zamieszkali oni z rodzicami w Pałacu Błękitnym. Ojciec osadził ich - jak zwykle - daleko od pałacu, w starym, ponurym domu przy ulicy Freta, naprzeciwko dominikanów. Na lato wyjechali do Wilanowa, posiadłości Potockich. Mieszkali w oficynie pałacu, pozostając do późnej jesieni. Służbę przy chłopcach i ich dwóch nauczycielach sprawował stary kościuszkowiec, krakowianin Szymon - człowiek pracowity, wesoły, żwawy i porządny. Wstawał wcześnie rano, budził chłopców o oznaczonej godzinie. Śniadania, obiady i kolacje przynosił z pobliskiej austerii. Gospodarstwo chłopców prowadzone było porządnie i jednocześnie bardzo oszczędnie, tak jak życzył sobie ich ojciec. Wynika zatem, że synowie Stanisława Kostki Zamoyskiego korzystali jedynie z terenów Wilanowa, nie mieszkali w pałacu, a w oficynie, nie byli na utrzymaniu Potockich, tylko musieli przystosować się do prowadzenia własnego utrzymania według wskazówek ojca. Na lato w roku 1815 i 1816 pozwolono chłopcom przyjechać z dwoma nauczycielami do Podzamcza pod Maciejowicami, majątku rodziców, gdzie obok nauki mieli dużo zabawy ${ }^{3}$. W Podzamczu mieszkali, jak zwykle osobno, w domu folwarcznym. Była w nim obszerna sala, którą na imieniny lub urodziny rodziców dzieci zamieniały we wnętrze teatralne, przystrojone drzewkami przyniesionymi z lasu i kwiatami z ogrodu ${ }^{4}$. Zdaniem Stanisława Zamoyskiego, aby pozytywnie ukształtować charakter dziecka, czynić go otwartym, łagodnym, przystępnym, miłym, nauczyciel powinien dawać dobre przykłady swojego postępowania. Dzieci nie należy upokarzać, przeciwnie zachęcać, ale także nie podchlebiać się im. Rozwój umysłowy dzieci powinien iść w parze z rozwojem fizycznym, dlatego też miały obowiązek uprawiania ćwiczeń gimnastycznych, a także uprawiać szermierkę, ćwiczyć się w walce na florety, szpady lub szable. W niedziele i święta dzieci miały obowiązek uczestniczyć we mszy świętej i w kościele pilnie się modlić.

\footnotetext{
3 AGAD, AZ, sygn. k. 1, 2, 9; sygn. 2108, k. 5, 6, 9 , 10.

${ }^{4}$ Ibidem, sygn. 107, k. 5-7.
} 
Instrukcje tyczące wychowania i kształcenia dzieci XII ordynata na Zamościu miały na celu ukształtować godnych obywateli ojczyzny i synów rodu Zamoyskich. Dzieci ordynata wychowywane były w posłuszeństwie woli rodziców i szacunku wobec nich.

Chłopcy na spacerze nie powinni prowadzić rozmowy ze służącym ani z kimkolwiek na ulicy. W pomieszczeniach przeznaczonych do nauki nie wolno im było przyjmować żadnych wizyt. Pokój, w którym odbywała się nauka, był ogrzewany piecem, każdy z chłopców miał swój stolik, na nim nie mogło być żadnej zabawki, lecz tylko rzeczy potrzebne do nauki. Zabawki owszem były, ale znajdowały się w miejscu specjalnie do tego przeznaczonym, porządnie ułożone, bo - jak twierdził Stanisław K. Zamoyski - regularność i porzadek, sa to dwie rzeczy najpotrzebniejsze człowiekowi, które od najmłodszych lat $w$ natóg obrócić trzeba ${ }^{5}$.

Dzieci Stanisława Kostki Zamyskiego wychowywane były w dużej oszczędności przekraczała ona niekiedy przyjęte wówczas normy. Podczas pobierania nauki przez chłopców w Paryżu (1813 r.), jeden z ich nauczycieli-wychowawców w listach pisanych do S. Kostki Zamoyskiego czynił spostrzeżenia, że zapewne źle rozumiane oszczędzanie było powodem, że chłopcy chodzili w połatanych sukniach, różniąc się ubiorem od innych. Podpowiadał, że zostając w czasie wakacji w Paryżu, dzieci powinny zwiedzić jego okolice, tzn. Wersal, Malmaison, Fontainebleau, poznać stosowne do wieku niewinne rozrywki teatralne, pantomimę, koncerty, ćwiczenia fizyczne. Byłaby to dla chłopców nagroda i zachęta do nauki, a jednocześnie wywiezione spostrzeżenia byłyby tematami do pożytecznych rozmów i porównania widzianych rzeczy. Propozycje nie znalazły realizacji z racji wydatków.

Rodzice nieustannie przypominali dzieciom, że jest wprawdzie znaczny majątek, ale tylko najstarszy syn odziedziczy ordynację, młodsi muszą natomiast zdobywać kwalifikacje, aby w przyszłości zapracować na swoje utrzymanie. Powinni również umieć przyzwyczajać się do ubóstwa. Dzieciom trudno było zrozumieć, jak mają przyzwyczajać się do ubóstwa w swoim tak zamożnym domu, przy takim położeniu i odpowiednich stosunkach. Jadwiga, żona księcia Leona Sapiehy, po latach tak mówiła o traktowaniu córek przez ojca Stanisława Kostkę Zamoyskiego: Wszystko co najgorsze to zawsze było dla nas. [...] Najgorszy, staroświecki powóz, najgorsze konie, najmniej pokaźny stangret wywozili panienki na przechadzke piesza za miasto, ażeby w Ogrodzie Saskim i na Alejach się nie spotykały ze znajomymi i znajomości nie zawierały. Ubrane z najsurowsza oszczędnościa jadly z nauczycielka przy nader skromnym stole i uczyć się musiały nieskończenie długo o Medach i Persach, póki z dala je dolatywały dźwięki muzyki balowej, lub turkot zajeżdzajacych i odjeżḋajacych powozów ${ }^{6}$.

Po ukończeniu nauki w Warszawie (1816 r.) nadszedł czas na poważne zagraniczne peregrynacje edukacyjne. Stanisław K. Zamoyski zdecydował, że jego starsi czterej synowie dalszą naukę odbywać będą w Genewie. Widać, że w porównaniu z edukacyjnymi wyjazdami zagranicznymi polskiej młodzieży w XVI i XVII w. nastąpiła zmiana miej-

\footnotetext{
5 Ibidem, sygn., 108, k. 6.

${ }^{6}$ J. Zamoyska, Wspomnienia. Rękopis opracowała, poprzedziła wstępem, zaopatrzyła w przypisy i indeksy Maria Czapska, Wyd. B. Świderski - Londyn 1961, s. 5.
} 
sca. Poprzednio katolicy zwykle kierowali się utartym szlakiem ku krajom wyraźnie katolickim, a różnowiercy wybierali państwa bliskie ich zainteresowaniom religijnym. W rodzinie Stanisława K. Zamoyskiego dzieje się zupełnie inaczej - katolicki dom XII ordynata na Zamościu wybiera na miejsce nauki swoich synów protestancki ośrodek, jakim była na początku XIX w. Genewa. Były niewątpliwie ku temu ważne powody. Otóż w okresie panowania Napoleona I we Francji, kanton genewski wcielony został do cesarstwa francuskiego, bliskie zatem kontakty z Paryżem i dworem wersalskim przydały genewskiemu otoczeniu ogromną i niezwykłą ogładę, co w połączeniu z wysokim poziomem nauczania w miejscowych szkołach sprawiało, że wybierano Genewę jako miejsce bardzo stosowne dla dorastającej i zdobywającej wiedzę młodzieży. Wspomnieć należy, że rodzice, posyłając synów za granicę w celach edukacyjnych, wybierali ośrodki dające naukę, obycie towarzyskie, ale zwracali także baczną uwagę na panującą tam moralność, aby uchronić dzieci swoje od złego towarzystwa i rozpusty. Szkoły genewskie były wprawdzie protestanckie i choć istniała opinia, że panowała tam atmosfera sprzyjająca kształceniu pastorów, to wiadomo było, iż nie ma tam siedliska rozpusty i lekceważenia religii. Aby zatem ustrzec synów od nieprawości tego świata, Stanisław K. Zamoyski wybrał dla nich protestancką Genewę. Było tam skromne i niewystawne życie.

Po ukończeniu nauki w akademii genewskiej Konstanty i Artur Andrzej za polecenie ojca udali się na dalszą naukę do Edynburga. Jan i Władysław zostali jeszcze w Genewie, a potem musieli się udać do Berlina, chociaż bardzo chcieli do braci do Anglii. Decyzja ojca była niezmienną. Przy czym Stanisław K. Zamoyski przekazał listownie guwernerowi panu Lambertowi, aby objął nad synami w Berlinie ścisłą opiekę, inaczej mówiąc: dozór. Chłopcy byli bardzo zdziwieni postanowieniem ojca, bo już w Genewie korzystali przecież ze znacznej swobody. XII ordynat na Zamościu twierdził, że synowie są w takim wieku, że w znanym z zepsucia Berlinie jest im potrzebny większy dozór.

Jan i Władysław na wyraźne życzenie ojca nie zapisali się na regularne studia na uniwersytecie berlińskim. Wynikało to z faktu, że wówczas w Królestwie Polskim, wielki książę Konstanty patrzył podejrzliwie na uczącą się młodzież $\dot{z}^{7}$ Ordynat ostrzegał nieustannie synów w listach, że niewątpliwie otaczają ich szpiedzy, śledzą ich otoczenie, rozmowy i zapewne donoszą to wszystko odpowiednim służbom. Powinni zatem zachowywać się tak, aby nie myślano o nich jako o kształcących się na uniwersytecie, ale, że głównym celem ich pobytu w Berlinie jest nauka języka niemieckiego. Młodzi Zamoyscy musieli respektować wolę ojca, a wynikająca stąd ich postawa powodowała nieprzyjemne dla nich sytuacje w środowisku polskich studentów.

W czasie zagranicznych peregrynacji edukacyjnych, synowie Stanisława K. Zamoyskiego mimo silnej tęsknoty za domem rodzinnym z woli ojca pozostawali na czas wakacji także za granicą. Latem 1821 r., po pięciu latach pobytu poza ojczyzną, XII ordynat na Zamościu zezwolił wreszcie synom na przyjazd do Podzamcza.

Model wychowania synów, nakreślony przez Stanisława Kostkę Zamoyskiego, prowadzony twardą ręką, ale także z miłością i rozsądkiem rodziców służyć miał ukształto-

${ }^{7}$ W. Zamoyski, Jenerał Zamoyski 1803-1863, t.I, Poznań 1910, s.103. 
waniu potomstwa w głębokim przeświadczeniu miłości i służby dla ojczyzny. Dzieci Stanisława Kostki Zamoyskiego w dorosłym życiu chciały jak najlepiej ofiarować jej wszystkie swoje zdobyte umiejętności.

Celestyna z Zamoyskich Działyńska była córką Zofii z Czartoryskich i Stanisława Kostki Zamoyskiego, XII ordynata na Zamościu. Urodziła się 16 września 1804 r. w zamku w Zamościu . Była piątym dzieckiem Zamoyskich, ale pierwszą córką i pierwszym dzieckiem urodzonym w Zamościu. Powitano ją z wielką radością kilkunastoma wystrzałami armatnimi z twierdzy zamojskiej. Na chrzcie otrzymała imię Gryzelda - jak pisze we Wspomnieniach jej córka, Jadwiga z Działyńskich Zamoyska: „,na pamiątkę Gryzeldy Batorówny, małżonki Jana Zamoyskiego, Wielkiego Kanclerza i Hetmana. Później nie wiem czemu, zamieniono to świetne i historyczne imię Gryzeldy, na imię Celiny"9. W dokumentach oficjalnych występują imiona: Gryzelda Celestyna, a w bliskiej rodzinie używano imienia Celina. Materiały archiwalne mówią o szerszym zakresie imion pierwszej córki pary ordynackiej. Wiadomość zawarta jest w wierszu (wiązaniu), ofiarowanym z życzeniami od Walentego Kamińskiego, mianowicie: „Jaśnie Wielmożnej Imci pannie Celestynie, Gryzeldzie, Konstancji, Elżbiecie z domu Zamoyskich i Czartoryskich hrabiance Ordynatównie Zamoyskiej w dniu Imienin r. 180425 września ofiarowane Wiązanie" $"$.

W 1825 r., 19 listopada, Celestyna Zamoyska została żoną hrabiego Tytusa Działyńskiego. Wkrótce po uroczystościach ślubnych Działyńscy udali się do Kórnika i Pałacu Działyńskich w Poznaniu. Spokojny byt rodziny zakłócił wybuch powstania listopadowego. Mąż Celestyny Tytus Działyński na wieść o powstaniu zaciągnął się do pułków Poznańskich i jako jeden z pierwszych znalazł się na polu bitwy. Celestyna została w Poznaniu, odbierając od męża wiadomości o wydarzeniach warszawskich oraz wskazówki, co powinni czynić Wielkopolanie, aby pomóc powstańcom. Wkrótce sama także udała się do Warszawy, kierując się wyniesionym z domu rodzinnego gorącym przesłaniem ofiarowania pomocy umiłowanej ojczyźnie w potrzebie. Tam razem z siostrą męża, Klaudyną Potocką z Działyńskich, zajmowała się urządzaniem lazaretów dla rannych powstańców, gromadzeniem leków i materiałów opatrunkowych ${ }^{11}$. Po upadku powstania opuściła Warszawę, udając się z dziećmi i Czartoryskimi do Krakowa.

Tytus Działyński za udział w powstaniu oskarżony został przez władze pruskie o zdradę stanu, a jego kórnicki majątek zasekwestrowano. Powrót do Księstwa Poznańskiego groził Działyńskim więzieniem. Tytus Działyński został więc bez dochodów, podobnie było z dochodami żony. Majątek bowiem posagowy Celestyny Działyńskiej Ręczaje w Królestwie Polskim, po upadku powstania również był niedostępny dla Działyńskich. Początkowo schronienie znaleźli u Arturowej Potockiej w Krakowie w Pałacu pod Baranami. Mieszkanie było wygodne i przestronne, ale utrzymywać musieli się

\footnotetext{
${ }^{8}$ AGAD, AZ, sygn. 2708, s. 2.

9 J. Zamoyska, Wspomnienia, s. 3.

${ }^{10}$ AGAD, AZ, sygn. 109, k. 9.

${ }^{11}$ Sylwetki wybitnych ludzi ziemi kórnickiej, Stanisław Potocki, Celestyna z Zamoyskich Dzialyńska 1804-1883, Poznań 1987, s. 12.
} 
sami, a w obliczu zaistniałej sytuacji brak było wydatków na żywność. Działyńska wychowywana w twardych warunkach i oszczędności w domu swoich rodziców nie skarżyła się na przeciwności losu, starała się, aby lepsze jedzenie dostawały dzieci, ukrywając swoją nędzę przed resztą rodziny. Karmiono się głównie chlebem razowym. Kawa i herbata rzadko były na stole. Podstawę obiadu stanowiły ziemniaki w mundurkach bez masła i soli. To trudne położenie zmusiło Działyńskich do opuszczenia Krakowa. Dalsza wędrówka u krewnych nie przedstawiała się lepiej, skoro po latach Jadwiga Zamoyska, córka Celestyny pisała, że w Wysocku była nędza, w Żurawicy bieda, a w Zarzycach wielka oszczędność. Działyńscy osiedli całą rodziną w Galicji w 1836 r. w Oleszycach pod Jarosławiem. Byli wreszcie u siebie i na swoim. Stanisław Kostka Zamoyski zamienił wówczas dobra Ręczaje w Królestwie na Oleszyce z kilkoma folwarkami. Działyńscy zastali tam wielkie zaniedbanie majątku i pełnię systemu pańszczyźnianego. Dominium było jednocześnie jednostką administracyjną, a właściciel majątku sprawował wobec poddanych władzę policyjną, fiskalną, sądową i odpowiadał za pobór rekruta. Handel i karczmy były w rękach Żydów. Szkoły katolickiej w Oleszycach nie było. Istniała dla ludności wyznania prawosławnego. Nauczycielem w niej był - kiedy miał na to czas diak, czyli sługa kościelny ${ }^{12}$.

Działyńscy chcieli zmienić zastałą sytuację w Oleszycach i pomóc włościanom. Postanowili w swoich dobrach oleszyckich wyzwolić chłopów od pańszczyzny i oczynszować ich. Nie było to łatwe. Chłopi niedowierzali, że coś takiego może się stać, rząd sprzeciwiał się, a zaniepokojeni sąsiedzi nie patrzyli życzliwym okiem. Celestyna Działyńska pomagała mężowi w realizacji jego planów, ale sobie wyznaczyła również ważne cele wobec galicyjskiego chłopstwa. Niewątpliwie istotną rolę odgrywały tutaj wartości wyniesione $\mathrm{z}$ wychowania $\mathrm{w}$ domu rodzinnym, gdzie mówiło się o szacunku i pomocy dla tych, którzy jej potrzebują. Dzielnie więc zajmowała się chorymi włościanami. Każdego dnia jeździła na małej chłopskiej klaczce z workiem lekarstw i żywnością dla chorych. Po obiedzie opatrywała rany w domu, szyła bieliznę dla chorych włościan.

Odnośnie co do wychowania swoich dzieci przez Działyńskich, nie natrafiono na gotową instrukcję, najprawdopodobniej jej nie było. Wydaje się, że sytuacja polityczno-społeczna, w jakiej znaleźli się Działyńscy, nie sprzyjała takiemu przedsięwzięciu. Z obserwacji zachowań dzieci Działyńskich zawartych w źródłach wynika, że dzieci wychowywane były w oparciu o przykłady domu rodzinnego i wzór do naśladowania ze strony rodziców. Tak np., widząc zachowania matki wobec chłopów, dzieci Działyńskich także uczestniczyły w pomocy włościanom Oleszyc. Składały się razem ze swoich oszczędności na kupno korca soli, krup lub grochu i miarkami nosiły do biednych. Małoletnie córki Celiny Działyńskiej własnoręcznie przygotowywały również wyprawki dla maleńkich dzieci chłopskich. Szyły po trochu codziennie, aby uczynić matce radość na dzień jej urodzin 16 września, przynosząc gotowe koszulki, czapeczki, powijaki itp., które ona potem ofiarowała włościanom ${ }^{13}$. Same uczyły się przez to pracowitości, oszczędności, kroju i szycia oraz miały satysfakcję, że cieszyły matkę swoim postępowa-

\footnotetext{
12 J. Zamoyska, Wspomnienia, s. 39.

13 Ibidem, s. 38.
} 
niem. Widać w postępowaniu dzieci miłość do matki, aby przez swoją pracę przynieść zadowolenie matce, którą bardzo kochały. Pomagały również matce przy organizowaniu szkoły dla dzieci włościan oleszyckich. Szkoła z powodu trudności lokalowych mieściła się początkowo w stodole, później wybudowano dla niej murowany budynek. W organizowaniu nauki wiele wkładu było guwernantki dzieci Działyńskich, Angielki, panny Birt. Ona sprowadziła wzory tablic szkolnych, według nowej istniejącej wówczas w Anglii metody nauczania Lancastra, czyli wzajemnej nauki. Jadwiga Zamoyska pisała we Wspomnieniach, że: Wedtug tych wzorów drukowaliśmy wszyscy, a raczej pisaliśmy drukowanymi literami, tablice po polsku: liczby, litery, zgłoski, słowa, a nareszcie całe modlitwy, pieśni, bajki do których moja Matka malowała ilustracje ${ }^{14}$. Ten system nauki polegał na nauczaniu przez nauczyciela najstarszych i najzdolniejszych dzieci, które z kolei uczyły mniejsze grupki młodszych, opiekując się jednocześnie nimi. Szkółki tego typu zakładane były przez Celestynę Działyńską także i w innych wsiach należących do dóbr oleszyckich. Zamierzała prawdopodobnie zorganizować także szkołę dla parobków, jaką stworzył w Podzamczu jej ojciec Stanisław Kostka Zamoyski. O szkole tej pisze w jednym z listów do córki, twierdząc, że wiadomości te będą bardzo przydatne Działyńskiej w jej zamiarach dobroczynnych dla włościan ${ }^{15}$.

Dzieci Celestyny i Tytusa Działyńskich wychowywane były w dużej oszczędności. Nie wynikało to jednakże z przesadnego skąpstwa wobec nich. Powodem była trudna sytuacja materialna rodziny i dzieci, które wiedząc o tym, stan ten znosiły z godnością. Pisze o tym córka Działyńskiej, Jadwiga Zamoyska, z czasów pobytu w Oleszycach: Mógłby ktoś pomyśleć, że moi Rodzice tyle czyniąc dobrego dla biednych, musieli mieć znaczne dochody. Bynajmniej. Oleszyce mogty nas jako tako wyżywić i to zaledwie przy największej oszczędności, ale poza tym co ziemia dawała na nasze wyżwienie, istotna była bieda. Kórnik zawsze jeszcze byt w sekwestrze i mój Ociec nie miał grosza dochodu. Sam często mówił, że byt na łaskawym chlebie u mojej Matki, albo że byt jej ekonomem. Stary kredencarz moich rodziców, Karol, więcej się jeszcze troszczył o oszczędności niż moi rodzice, którzy się z catym gospodarstwem domowym na niego spuszczali. Karol trzymat klucze od wszystkiego, dawat co chciat dać, a czego nie chciat to nie dawat. [...] Moi Rodzice dobrze sie pod tym względem dobrali, bo nigdy nie wiedzieli co i jak jedli, a czasem, gdy pan Zdzisław Zamoyski, albo księżna Leonowa, zjawiali się w Oleszycach $i$ utyskiwali, że nigdy nie ma u nas świeżego chleba, ani butki $i$, że chyba , stare się rodza”, a moja Matka robiła o tym uwage Karolowi, na to on jej odpowiadat: „Jakby byty świeże, to by ich dwa razy więcej zjedli”. Na tej samej zasadzie, dawat nam przez wszystkie dni postne całego roku sto ckfis z a na obiad. Było to coś tak okropnego, że prawdopodobnie, ten sam pótmisek mógł kilkanaście razy z rzędu na stole figurować, tak mało kto się na niego odważyt $i$ tak mało go ubywało za każdym razem. Na śniadanie, co dzień, przez dwadzieścia lat, kasza na wodzie bez masła, a w niedziele kawa żołędziowa. Na wielkie gala na obiad budyń z szodonem, zwany przez nas ,, baba szalona”, na który

\footnotetext{
14 Ibidem, s. 41.

${ }^{15}$ Biblioteka Kórnicka, rkps. 1631, k. 7, Akta szkoły parobczej na Podzamczu w Maciejowicach w dobrach ... ordynata Zamoyskiego.
} 
także patrzeć się nie mogłam. Z ubraniem nie lepiej było. Kupowano w Jarosławiu jakieś materie na suknie jednakowe dla mojej siostry i dla mnie. Ktoś poradzit, ażeby wybierano materiaty $w$ kratki, bo tatwiejsze sa do łatania, a więc kupowano jakieś flanele, w czarne i granatowe, albo czarne i passowe kratki. Jakeśmy już z nich wyrastały, robiono z dwóch jedna dla mojej siostry, a jak ona znów wyrosła to ją przerabiano dla mnie! Biedna panna Birt głowę sobie tamała i robiła i czyściła, i łatała, ażeby dać temu jaki taki pozór, ale nieraz było jej markotno, że tak około nas biednie, a mianowicie kiedyśmy się gdzieś zjeżḋali z ciotecznymi i wujecznymi braćmi. Przypomina mi się, jak raz, nie pamiętam gdzie to być mogło, nasza służaca zapytała piastunki Sapiehów: „, Gdzie wy dajecie naprawiać trzewiki waszych dzieci?” - „Nasze dzieci nie nosza naprawianych trzewików" - odrzekła tamta. To mi dużo dało do myślenia. Czy te dzieci takie grzeczne pomyślałam sobie - że nigdy trzewików nie drą, czy też jak podra musza w podartych chodzić. Trudna była dla mnie zagadka do rozwiazania, ale po minie obu sług miarkowałam, że coś tam tkwi niepochlebnego dla nas ${ }^{16}$.

W 1839 r. Tytus Działyński wreszcie odzyskał dobra kórnickie od władz pruskich. W 1842 r. Działyńska z czterema córkami powróciła do Kórnika. Mieszkała głównie w pałacu poznańskim, a latem przeważnie w Kórniku. Tutaj znany społecznik poznański doktor Karol Marcinkowski, zwrócił się do niej o pomoc w pracy filantropijnej na rzecz ubogich i chorych. Działyńska przystąpiła do tej pracy z dużym zaangażowaniem. W 1844 r. założyła Towarzystwo Dobroczynności Dam Polskich, którego została prezeską ${ }^{17}$, przekształcone w 1853 r. w Towarzystwo Pań Miłosierdzia św. Winncentego a Paulo kierowało pracą charytatywną. Natomiast do bezpośredniej pracy z chorymi i ubogimi wybrała Zakon Sióstr Miłosierdzia św. Winncentego a Paulo, zwany popularnie szarytkami, który sprowadziła do Poznania. Zakonnice szarytki zajmowały się pracą wśród ubogich, opieką nad szpitalami, prowadzeniem ochronek ${ }^{18}$.

Dzieci Celiny i Tytusa Działyńskich wychowywane w przywiązaniu i miłości do rodziców, wspierały matkę w jej działalności społecznikowskiej i pomagały w niesieniu pomocy ojczyźnie w potrzebie. Wyrazem tego jest chociażby postawa jej córki Anny, kiedy to Działyńska zaangażowała się w niesienie pomocy uczestnikom powstania styczniowego 1863 r. Utworzony przez nią komitet przygotowywał odzież i zbierał żywność dla powstańców. Anna razem z matką chodziły od sklepu do sklepu, prosząc o poparcie sprawy, czym kto mógł. Parę słów po cichu wypowiedzianych wystarczyło, poczciwi kupcy nasi z zapałem w oku przejmowali kwestę. W kilka godzin potem pomieścić nie można było towarów naniesionych. Pamiętam jeszcze te ogromne bele płótna, flaneli, sukna, stosy ciepłych rękawic, filcowych butów, wreszcie cygar i wódek. Cały dzień $w$ domu $i$ cata noc prawie krajano, fastrygowano i robote po domach roznoszono. Wieczorem przy czytaniu gazet robiliśmy szarpie i krajaty bandaż $e^{19}$.

\footnotetext{
${ }^{16}$ J. Zamoyska, Wspomnienia, s. 44, 45.

17 Sylwetki wybitnych ludzi..., s. 14.

18 Ibidem, s. 15.

19 Ibidem, s. 16.
} 
W kwietniu 1863 r. w czasie rewizji przeprowadzonej w Pałacu Działyńskich w Poznaniu przez policję pruską, znaleziono notatki Jana Działyńskiego - syna Celestyny, obciążające go działalnością na rzecz powstania. Działyński uratował się ucieczką. Celestynie również groziło aresztowanie. Wyjechała więc pilnie z dwoma młodszymi córkami do Drezna. Majątek kórnicki znowu został zasekwestrowany. Działyńska wróciła do Poznania po kilku latach, kiedy syn Jan odzyskał majątek na mocy amnestii i wrócił do Kórnika.

Przedstawiona powyżej charakterystyka modelu wychowania dzieci w rodzinie ziemiańskiej w pierwszej połowie XIX w. na przykładzie domu Stanisława Kostki Zamoyskiego i jego córki Celiny Działyńskiej ukazuje różnice, ale i podobieństwa. Wychowanie i kształcenie synów Stanisława K. Zamoyskiego przebiegało według instrukcji przez niego sporządzonych. Instrukcji takowych dla dzieci Celestyny (Celiny) i Tytusa Działyńskich nie było. Być może dlatego, że w rodzinie Działyńskich były głównie córki, a generalnie dla nich nie spotyka się w źródłach instrukcji tyczących ich wychowania. Zwracano dużą uwagę na oszczędność i praktyczność. W rodzinie Działyńskich wychowywanie dzieci przypadło na trudny okres zawirowań powstania listopadowego związanych z utratą majątku i właściwie bieda dyktowała prowadzenie bardzo oszczędnego trybu życia. Celina Działyńska uczyła swoje dzieci szacunku dla prostych ludzi - służby. Zarówno w domu Stanisława K. Zamoyskiego, jak i Celestyny Działyńskiej dzieci wychowywano w posłuszeństwie, szacunku i miłości do rodziców, jak również rodzeństwa wobec siebie. Miały nieść pomoc potrzebującym oraz kochać swoją ojczyznę i ofiarnie jej służyć. Dzieci wychowywane w ten sposób stawały się w życiu dorosłym osobami świadomymi swych obowiązków wobec rodziny i ojczyzny. 